\section{GYÖRI Zsuzsanna}

\section{ELSÖ- ÉS MÁSODFAJÚ ETIKAI KUDARCOK}

A cikkben a szerző a piac és a kormányzat kudarcaiból kiindulva azonosítja a közjó elérését célzó harmadik rendszer, az etikai felelôsség kudarcait. Statisztikai analógiát használva elsófajú kudarcként azonosítja, mikor az etikát nem veszik figyelembe, pedig szükség van rá. Ugyanakkor másodfajú kudarcként kezeli az etika profitnövelést célzó használatát, mely megtéveszti az érintetteteket, így még szélesebb utat enged az opportunista üzleti tevékenységnek. Meglátása szerint a három rendszer egymást nemcsak kiegészíti, de kölcsönösen korrigálja is. Ez az elsôfajú kudarc esetében általánosabb, a másodfajú kudarc megoldásához azonban a gazdasági élet alapvetéseinek átfogalmazására, az önérdek és az egydimenziós teljesítményértékelés helyett egy új, holisztikusabb szemléletú közgazdaságra van szükség.

Kulcsszavak: társadalmi felelósségvállalás, vállalati etika, kudarcok

Bár Amerikában a vállalatok társadalmi felelőssége jogon « veszi figyelembe szempontjainkat" (Goodpaster már a hatvanas-hetvenes években terítékre került - ezt - Matthews in: Boda - Radácsi, 1997: 30. o.). Ez a probbizonyítja Friedman 1970-ben megjelent cikke, ahol léma képezi cikkem mondanivalójának alapját, de elóbb 1970-ben megjelent cikke, ahol már arról beszél, milyen veszélyes a tulajdonosok és a kapitalista rendszer szempontjából, ha a vállalatok komolyan vesznek olyan feladatokat, mint a munk helyteremtés, a diszkrimináció visszaszorítása vagy környezetszennyezés csökkentése -, mégis az elsố legfontosabb elméleti tanulmány a témáról Goodpaster es Matthews: Lehet-e a vállalatnak lelkiismerete? cím cikke. Természetesen elóbb is megfogalmazódtak gondolatok az üzlet felelősségéről, de korábban fókén az üzletemberek egyéni felelősségét hangsúlyozták ${ }^{2}$. A mú azért is mérföldkő, mert tisztázták benne, hogy a társadalmi felelósségvállalás nem a rendszer gyökeres megváltoztatását célozza, nem akar szocializmust, ahogy attól Friedman tartott, hanem egy újfajta kapitalista felfogást testesít meg.

Amikor 1982-ben megírták korszakalkotó cikküket a vállalatok felelôsségvállalásáról, még egész másra he lyezték az elemzés hangsúlyát, mint napjainkban tesszük, bár már ebben a tanulmányban is megemlítik a „,ne saját jogú" (instrumentális) etika veszélyének lehetôségét, de csak az egyéni felelősséggel kapcsolatban. A ma helyzet ismeretében visszanézve talán kicsit naivan azt állítják, hogy ösztönösen tudjuk, egy felelốs személy „nem csupán a »tisztesség a leginkább kifizetôdő politika« jegyében, hanem mint önmagában fontosat, »saj ena képezi cikkem mondanivalojának alapj

A tanulmány fókuszpontja az egyéni felelősség mibenlétének tisztázása, és ezután a fogalom értelmezése nem csak az egyes emberre, de emberek olyan szervezett csoportjára is, mint egy vállalat. Ebben az idóben még kérdéses volt, van-e egyáltalán szerepe az etikának, erkölcsi megontolásoknak a gazdasági életben, a vállalatok mindennapjaiban.

Ma már egyre szélesebb körben elfogadott, hogy az egyének nem viselkedhetnek tökéletesen más logika és normák alapján vállalatvezetốként, mint más társadalmi szerepeikben, Goodpaster, (2007) késốbb ezt morális skizofrénínak neveri. A k

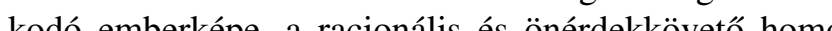

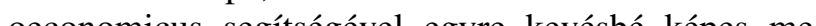
oecono magyarázni és elóre jelezni a gazdasági folyamatokat zok hatásait a társadalmi, ökológiai folyamatokra.

A gazdaságetika emberképe Amitai Etzion szocioookonomiai elmélete (in: Kindler - Zsolnai, 1993) szerint sokkal árnyaltabb, több tényező́t vesz figyelembe az emberi cselekvés megjósolása folyamán: figyelembe veszí, hogy a dôntéshozó hasznosságán kívül az etikai megfontolások is szerepet játszanak. Továbbmenve azt állapítja meg, hogy az emberek döntéseiknél nem maximalizáló, hanem egyensúlyozó tevékenységet végez-

VEZETÉSTUDOMÁNY

nek - egyensúlyra törekszenek a hasznosság és az etika között. Goodpaster és Matthews is hasonlót állapít meg az emberi felelốsségról: döntéshozatali értelembe ,azokat tartjuk felelős személyeknek, akik cselekedeteikben megbízhatóak, véleménynyilvánításukban hitel érdemlőek, ítéleteiket mindig a körülmények messzemenő figyelembevételével alakítják ki" (Goodpaster Matthews in: Boda - Radácsi, 1997: 29. o.)

Frankena alapján a felelősségnek két alapvető elemét hangsúlyozzák: a racionalitást és a respektust, vagyis a döntések másokra gyakorolt hatáśn dótés az ezzel való törő́dést. A két szerzô nem nevezígy de a racionatrónt a Simon-fóle procedurális nevezi így, de a racion értelemben

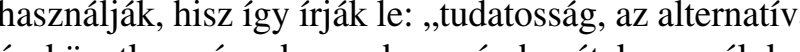
es következmények gondos szâmbavêtele, a célok szándékok korültekintó tisztázása és a végrehajtás részletei iránt tanústott figyelem" (Goodpaster - Matthew in: Boda - Radácsi, 1997: 30. o.). A felelősség valójába válaszadási képesség és kötelesség ${ }^{3}$, a felelősségvállal pedig gondosságot, a következmények figyelembevéteét és aktív szerepvállalást jelent (Angyal, 2003).

Az egyéni felelósség fogalmának tisztázása után a felelősség vállalatokra való kiterjesztésének jogosságát támasztják alá: mivel a csoportokba szervezett emberek bizonyos esetekben képesek úgy viselkedni, mint egyetlen személy, és ez rúdásul a gazdaśgi ćlet alopját adó igazś́ természetes gond a felelós alap-

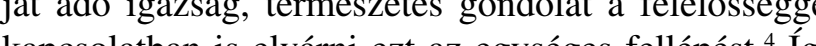
kapcsóni flock az egyeni felelosseg an is két dolgot követelnek meg. racionalitást és a döntések másokra való hatásainak figyelembevételét, vagyis respektust. A vállalati felelősség tehát lehetséges vállalatnak lehet lelkiismerete.

Mégis kérdés marad, hogy kell-e élni ezzel a lehetőséggel, másként feltéve a kérdést: szükséges-e modern piaci rendszerben, hogy a vállalatok felelôse viselkedjenek üzleti és társadalmi interakcióik során. A tanulmány második része erre a kérdésre válaszo közgazdasáoi, elméleti oldalról közelítve a problémát. A vállalati felelősség ( a vállalatvezetés keze") két

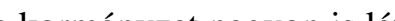

\section{A piac láthatatlan keze}

A láthatatlan kéz említésekor elsősorban Adam Smithre szoktak hivatkozni, a közgazdaságtan alapjait letevő múvébốl talán leggyakrabban citált gondolat miat: „Ebédünket nem a mészáros, a sörfőzó vagy a pék jóakaratától várjuk, hanem attól, hogy ezek a saját érdekeiket tartják szem elốtt. Nem emberiességükhöz, hanem önszeretetükhöz fordulunk, és sohasem a magunk

\section{VEZETÉSTUDOMÁNY}

zzükségéról, hanem a rájuk váró előnyökról beszélünk nekik.” (Smith, 1959: 64. o.) Végigolvasva a múvet zonban úgy tünik, Smith mosná kezeit, ha a mai álapotokat látná, ugyanis a mai piac alapjaiban tér el az oaltala felvázolt tơkéletes piactôl, melyen kellóképpen sokszámú és kis szereplő tökéletes informáltság mellett versenyez egymással. Azt is látnunk kell, hogy mint morálfilozófus, éppoly fontosnak tartotta a gazdaságban a morális megfontolásokat, mint az önérdekünkön és józan eszünkön alapuló piaci cserét. „Semmiképp sem tekinthetớ jó állampolgárnak az, aki nem segíti elô minden számára rendelkezésre álló eszközzel a közösThe Theory of Moral Seniozoseg joletét." (Smith: The Theory of Mont Sentiments. Igazság szerint nem

Igazság szerint nem szükséges Adam Smith védelmékelnem, hisz ezt megtette már többek között Amartya Sen Nobel-dijas közgazdász (1993), hangsúlyozva az uzzleti etika jelentôs szerepét a gazdaság megszervezésében, a termelés és elosztás lebonyolitásában. Sen hangsúlyozza, hogy bár Smith a csere fontos motivációs aktorának tartotta az onerdeket, korántsem hitte, hogy a gazdasági cselekvés csupán cserébốl állna, és hogy az eredmény szempontjából közömbös lenne, hogy „,az önérdeküktól vezérelt vállalkozások megpróbálják-e megkárosítani a fogyasztókat, vagy a fogyasztók megpróbálJák-e becsapni az eladókat" (Sen, 1993: 103. o.).

$\mathrm{Az}$ önérdek tehát a cserének szükséges, de nem elégséges feltétele. A sikeres cserének szervezeti előfeltételei is vannak, ezek közül az egyik legfontosabb kölcsönös bizalom és kiszámíthatóóág, amely nélkül gazdasági szereplók nem, vagy csak nehézségek árán oötnének kölcsönösen gyümölcsöző üzleteket. Fontos megállapítás, hogy „a meghatározott magatartási szabályokba vetett kölcsönös bizalom általában implicit, es nem explicit módon jelentkezik - olyannyira, hogy amikor nincs velük probléma, gyakran figyelmen kívül is hagyják óket" (Sen, 1993: 104. o.). A szerző rámutat, hogy a volt szocialista országokban ez a probléma nagyon is létezik, épp a szereplók közz̈tti bizalom, min a csere szervezeti megalapozója, hiányzik, így nálunk a csere szervezetie na szalapozoja, hányzik, így nalunk helyezni, mint a fejlettebb kapitalista szerveződésű országokban.

A XX. században a láthatatlan kéz legnagyobb szózólója a Nobel-díjas közgazdász, Milton Friedman és övetối voltak, akik egyenesen a tulajdonosok pénzéel való visszaélésnek nevezik a gazdaságban az etikai megfontolások megjelenését („öncélú” etika). A racionális döntéshozatal során minden új dimenzió, mint optimalizálási feltétel, rontja a gazdasági dimenzióban elérhetố eredményt, így a pusztán közgazdasági logika alapján etikátlan.

VII ÉVF $9012,10.5 Z$ AMT/ISSN 


\section{A kormányzat látható keze}

A kormányzat keze megközelítés alapján a piac elégtelenségei, a piackudarcok (externáliák, potyautasjelenség. tökéletten információ, rōvidlátó preferenciák, közjavak dül, hanem a kormányzattal, a törvényhozással közösen fogja a kettốt egybeigazítani, tehát a magánérdeken al puló döntéseket a közjó felé terelni. Ez a felfogás eltekint attól az általánosan elfogadott ténytốl, hogy a jog és az erkölcs nem esik egybe, egyrészt mert a jogi szabá lyozás lassabban fejlődik, mint az etikai - ez különösen fontos a rendkívül gyorsan változó globalizált világban -, másrészt, mert nem minden etikai norma kodifikálki a társa ki a társadalmí együttélés minden területére (bár vannak ilyen törekvések), ezért a jogon kívuili szabalyok is indokoltak.” (Angyal, 2003: 17. o.) „Az erkölcs, ha úgy tetszik, a tôrvény puha oldala." (Angyal, 1997)

Bár a két elnevezés (a piac láthatatlan keze és a kormányzat keze) homlokegyenest ellentétes elméletekr utalna, a szerzők hangsúlyozzák, milyen szembetún konceptuális hasonlóság van a két felfogás között: „mindkét nézet azokba a szabály- és ösztönző-rendszerekbe helyezi az erkőlcsiséget, etikát, felelósséget és lelkiismeretet, amelyekbe a modern vállalat be van ágyazva. Mindkét fölfogás elveti a vállalatok mint társadalmi cselekvő alanyok erkölcsi ítélóképességének érvényre juttatását." (Goodpaster - Matthews in: Bod - Radácsi, 1997: 34 o.) Ezzel mindkét elmélet kizária a külônboozztetố sajâtossagát azonosictották - és csupán szabályok kovetesének felelósséget roja a válalatokr így azok csak gazdasági szempontok szerint értékelhe-

\section{A vállalatvezetés keze}

Elméletük, a vállalatvezetés keze elmélet ezzel szemben az egyéni, döntéshozói felelősséget kiterjeszti berek csoportja képes egységes fellépésre, kvázi egy személyként való megjelenésre a külvilág felé - ezt szemán a jogi személy kifejezés is -, és nem igazán takarja a jogi személy kifejezés is -, és nem igazán realisztikus az a feltételezés, hogy a vállalatvezetók, akik más szerepelkben felelôsen döntenek, az üzleti életbe ik figyelembevétele mellett, az ujj elképzelés szakít a normák kettósségével. „Nem szabad éles határvonala húzni az egyén magánjellegú eszméi, erőfeszítései és a vállalat intézményes erófeszítései közé. Az utóbbi az miatt a magán- és a közérdek eltér, így a piac nem egye ható és kikényszeríthetố. „A jog rendszere nem terjed döntéshozói felelőssé́get - amiben az egyéni felelősse mibenlétének tisztázásakor az erkölcsi felelôsség megvállalatokra, illetve azok vezetóire is. Mivel az emcsupán szabályokat kôvetnének a gazdasági érdeke-

elóbbire építhet, sốt arra is kell építenie." (Goodpaster Matthews in: Boda - Radácsi, 1997: 35. o.)

Bár 25 évvel az elsố tanulmány után jelent meg, érdemes megemlíteni Goodpaster: Conscience and corporate culture címú könyvét, melyben újabb érveket hoz a vállalati felelősség mellett, illetve az ellenérvekkel szemben. Legfontosabb a „Nemo Dat” elv (Goodpaster, 2007: 97. o.), mely szerint bár a profit a vállalat elsődleges célja, a befektető́k nem várhatják el a menedzserektốl, hogy ne tartsák be a társadalom általánosan elfogadott morális elvárásait. Olyan ez, mint hogy a szzilóket sem mentifel a jogi és etikai kötelezettsegek ab́l az, hogy gy kötelezettségek alól az, hogy gyermekük érdekében cselekszenek.

\section{Piac, kormányzat és etika}

A vállalatok döntései tehát nem alapulhatnak csupán gazdasági megfontolásokon, gazdasági racionalitáson, azokban figyelembe kell venni erkölcsi érveket is, ilyen módon lesznek a vállalati döntések egy felelôs szervezet döntései. Ez természetesen nem zárja ki a piaci ösztönzés és a jogszabályok szükségességét, de a vállalati felelósség érvényesülésének ezek mellett feltétele a döntéshozói felelősség, a racionalitás mellett a respektus megjelenése is.

A közjó elérését tehát a „három kéz”, a három nagy rendszer együtt biztosítja: szükségünk van a piac hatékonyságára, a törvényhozás megkérdőjelezhetetlenségére, ugyanakkor a vállalatvezetók egyéni döntéshozói felelősségére is. A piac kudarcait a kormányzat nem tudja egyedül feloldani, hiszen a kormányzati beavatkozás is kudarcokkal jár: ellentétes hatások esetén kiszámíthatatlan a szabályozás hatása, ráadásul a közösségi döntéshozatal sajátja, hogy hatékonysági veszteségek következnek be. Friedman és kovetố ezért is szorgalmazzák a minél kisebb állami apparátus és költségvetés használatát.

A kormányzat ezen és már említett kudarcait - ti. hogy a törvényhozás lassú folyamat, és nem lehetséges minden szabályszegést kontrollálni és szankcionálni - a vállalati felelôsség, az etika eliminálná az elmélet szerint.

A piac, a kormányzat, az etika és a közjo összefüggésrendszere

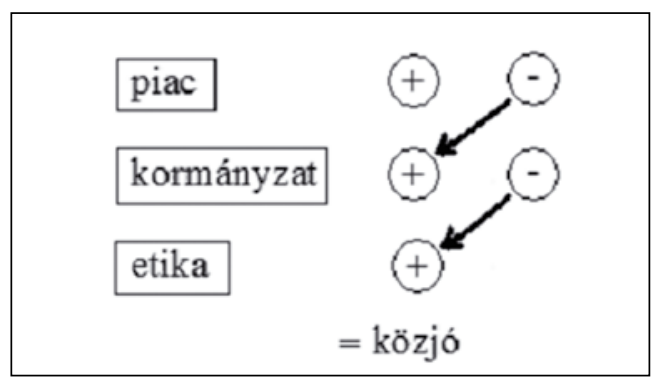

VEZETÉSTUDOMÁNY
Az 1. ábrán + jellel jelöltem, mikor az adott rendszer elemzésünk szempontjából, tehát a közjó előmozdításában jól funkcionál. A piacnak tehát vannak pozitív tulajdonságai: rendkívüil hatékonyan, a legkisebb ráfordítással aggregálja a fizetôképes szükségletet a keresletet. Mivel azonban a piac nem tökéletes (léteznek externáliák, közjószágok, monopóliumok), valamint nem minden szükséglet fizetốképes - így meg sem jelenik a piacon -, az aggregálás nem teljes körü (az ábrán - jel jelzi, ha az adott rendszer kudarcot vall). Ekkor lép be a kormányzat (az ábrán a nyilak jelzik, mikor az egyik rendszer kudarćt egy mósik javítja ki), anor azegyik rendszer kudacit egy a nyilak jel zik van tehát a harmadik kézre, mely biztosítja az egyéni közjó felé mutatását

Felmerül azonban, hogyha az elsố két rendszer nem mentes a kudarcoktól, vajon a harmadik tökéletes? É ha nem az, mi fog segíteni, hogy túllépjünk kudarcain? Egy negyedik rendszer? Vagy talán a másik ketto képes rá, és ezzel zárul a kör? Ha így van, azt jelenti, hogy nem lineáris fejlódési vonalat láthatunk, hanem három rendszer kölcsönösen meghatározza, korrigálja egymást. Véleményem szerint ez a helyzet, és miután kifejtem, mit értek pontosan az „etika kudarca” alatt, állításomat néhány jellemzô példa felvetésével szón kozom alátámasztani.

\section{A Ford Pinto-eset - példa a három kéz} kudarcaira

A Ford Pinto esete egyike a leghíresebb gazdaságetika eseteknek ${ }^{6}$. Jelen cikkben a három rendszer: a láthatalan kéz, a kormányzat keze és a vállalatvezetés keze kudarcait, és az ebből adódó problémákat szándékozom bemutatni.

Az 1970-es évek elején az USA-ban megnőtt a kiskategóriájú autók iránti igény. A VW bogár és a japán kiskocsik egyre népszerúbbek lettek, az amerikai autógyárak pedig nem tudtak konkurens terméket felmutatni. Ford vezetôsége, élén Lee lacoccával, úgy döntött, be kell szállni a versenybe, és ezért az akkor átlagos 43 hónap helyett 25 hónapot adtak mérnökeiknek az új autó, a Pinto megtervezésére. Az idô rövidsége azért volt problémás, mert akkoriban 18 hónap volt az összeszerelô sor legyártása, amit így jóval a tesztek befejezése elôtt meg kellett kezdeni. Amikor teh́t a tesztek soŕn meg kellt kezdeni. A ári tehát a tesztek során ón Pinto benzintartálya kilyukad, a benzin berobban, az autó kigyullad, már nem került sor az összeszerelố sor módosítására. Lehetőség lett volna rá, de ez egyrészt időveszteséget, másrészt súly, és áremelkedést jelentett volna, így nem teljesült volna a menedzsment ,2000-es célja”: az autónak 2000 fon súly és 2000 \$ ár alatt kellett piacra kerülnie. „Lee autója”, ahogy akkor a Fordnál nevezték, nem szenvedhette el azokat az egyszerú technikai változtatásokat - a mérnökök több alternatívát is javasoltak -, melyek autónként kb. 11 \$-ba kerültek volna, és jelentôsen növelték volna az autóban ülók biztonságát. De ahogy Iacocca fogalmazott: ,,a biztonság nem térül meg". A Pinto piacra került, és a kezdet tragédiáknál a Ford az utak minőségét, valamint az emberek rossz autóvezésés képescégeit hib́́ztatta

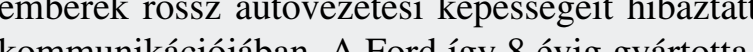
ko hate ến kártértési perekben a bíróságra. Még egy költség haszon elemzést is keszitettek, hogy bebizonyitsák hogy az amerikai nemzetgazdaság számára az az olcsóbb megoldás, ha évente pár százan megégnek vagy meghalnak kisebb balesetekben - melyek más autókban nem okoznának súlyos sérülést -, hiszen a minden autón elvégzendô változtatás összességében nagy költséggel járna. Az etika tehát kudarco vallott, hiszen bele sem került a vállalat vezetôinek gondolkodásába, döntési módszerébe.

De hol volt a piac? Miért vásárolták az emberek továbbra is az autót? Önérdeküket szolgálta a biztonság hiánya? A versenytársakhoz képest kedvező áron kínálták az autót, de kompenzálta-e az árdifferencia a kockázat nagymértékú növekedését? Ne feledjük, hogy a 70-es években járunk, az információáramlás még korántsem olyan gyors, mint napjainkban. A hatalmas ország különbözó pontjain történó tragédiák lassan álltak össze egységes képpé, miszerint a Ford Pinto nem biztonságos.

És hol volt a kormányzat, a szabályozás? Ha az információk terjedése lassú egy tökéletlen piacon, a központi szabályozás lenne hivatott azt felgyorsítani. Az Orszáos Országúti Forgalombiztonsági Hivatal 1972-ben tehát a piacra dobás után két évvel - kezdte el a Ford Pintók vizsgálatát, amely hat éven át tartott. Ezalatt a hat ev alatt a Ford továbbra sem javította ki a Pintók hibáját. 1978 májusában a hivatal befejezte a vizsgálatokat, es kijelentette, hogy a Pintók üzemanyagrendszere nem biztonságos, és követelte, hogy a Ford hívja vissza az autókat. Végül 1978. június 9-én a Ford vállalat megezdte 1,5 millió Pinto visszahívását (Bába, 2009).

\section{VEZETÉSTUDOMÁNY}


A kormányzat keze tehát végül megoldotta az etik mint döntési faktor kihagyásából származó problémát, de erre nyolc évet kellett várni. Ezalatt a nyolc év alat majdnem ezer ember halt meg Ford Pintóban történó, csak a tervezési hiba miatt súlyos, halálos kimenetelú balesetek miatt. Ezalatt ráadásul a Kanadában gyárto t Pintok már biztonságosak voltak, mert a kanadai kormány hamarabb bevezette a szigorúbb autóbiztonsági törvényeket.

Az eset kitúnóen bemutatja a piac kudarcát, mely az egyenlőtlen alkupozícióból, a tökéletlen információbó és a rövidlátó fogyasztói preferenciákból, a fogyasztók es a rôvido fogyastók szuverentán ugyanakkor a kornányzat legnagyobb kudarcát, az al acsony hatékonyságot, a tú nagy id henyt. És bennutatja, hogy mi tortenik, ha a fenti két rendszert nem egé szíti ki a felelôs vállalatvezetés, ha a profitéhség kizárja az egyéb fontos tényezók figyelembevételét.

\section{Az etika kudarcai}

Az etika elsőfajú kudarca, ahogy az esetbốl láttuk, ha nem is alkalmazzák, ha a vállalatvezetés annyira fontosnak tartja a profit növelését, hogy figyelmen kíviil hagyja döntéseinek társadalmi vagy környezeti hatásait. Ennek valószínúsége azonban - legalábbis látszólag - erôsen crölkent a 70-es évek, illetve Goodposterék cikeodpaster cikkének megitoza ota. Az eltelt 30 évben hatalm általánosabban elfogadott, hogy vállalatnak lehet lelkiáltalánosabban elfogadott, hogy vall

ismerete, sôt kell is, hogy legyen.

A vállalat társadalmi felelóssége, a „CSR” a poltikai és gazdasági párbeszéd, valamint gyakorlat tárgyává vált. Egyre több iránymutatás, ajánlás és nemzetközi szabvány születik a vállalatok felelősségének értékelésére, rangsorolására, a hozzá kapcsolódó politikák megfogalmazására. A vállalatvezetés keze elmélet köré hatalmas gyakorlati eszköztár épült, melyról az üzletemberek már az oktatásuk során is hallhatnak, melyeket tanácsadó cégek segítenek bevezetni, implemelyeket tanácsadó cé

$\mathrm{Az}$ érintettek kezdik felismerni saját érdekérvényesítố erejüket a vállalatokkal szemben, és egyre növekvớ mértékben ellenốrzést gyakorolnak a vállalatok tevékenysége fölött. A koncepciónak köszönhetően a vállalatok egy része felismerte felelősségét a társadalmi és környezeti állapotért, és ha mégsem, akkor is úgy viselkedik, „,mintha” számítana az etika, az érintettek jóindulatának megszerzése céljából. A legtöbb vállalat teh sajnálatos módon nem az etikai felelôsség szükségszerúségének felismerése miatt, hanem a jobb imázsért, reputációert foglalkozik a felelősségvállalással.
Az önérdeken alapuló, opportunista célokat szolgáb etikai gyakorlat mögött meghúzódó elmélet az üz. con, „CSR-t csinálni” jó és kívánatos, mert üzletileg, pénzügyi értelemben megtérül, mert a piaci szereplő́k elvárják azt, ső́t „okosan” használva stratégiai célokra is használható (1. Porter - Kramer, 2002, 2011). Természetesen a vállalati felelốsség mozgalom egyik hajtóerejét a tudatos és érdekeiket egyre inkább kifejezố érintettek adják. A fogyasztói igények minél teljesebb kielégítéséert folytatott harcban fontos fegyver lett az tikat folytatott harcban fontos fegyver lett az

A vállalat társadalmi felelőssége azonban eredetileg em erról szólt, és nem is erról kellene szólnia. A vállalati felelősség nem az érintettek elvárásaiból adódik, nem abból, hogy a mai világban úgy látszik, megéri felelôsen viselkedni, hanem abból, hogy a vállalatok óriási hatással vannak az érintettek életére, így nem hagyhatják figyelmen kívül ezt a hatást. Ez természetesen nem zárja ki a formalizálást vagy a stratégiaalkotást, de a felelősségnek át kell hatnia a vállalat teljes múködését, meg kell nyilvánulnia minden tevékenységben, és nem lehet fốként kommunikációs célokra használni.

Az üzleti érdek kritika nélküli, feltétlen igazságként való túlhangsúlyozása, és az erre épülő vállalati gyakorlat az etika , talan az elsog fancli is sureta ságetika paradoxonának nevezi a jelenséget, mikor az etikát profitnöveló eszkozzként használjuk, ezzel pont a gazdaságetika lényegét hagyva ki a „,elelős” visel-

Ha a gazdasági haszonnal, profittal támasztjuk alá az etika érvényességét, azzal igazából aláássuk, leértékeljük, hiszen megszunnik független dôntési kriterium enni, a profitszerzés eszköze lesz. Az etika a CSR-rel a felszínen nyert, de valójában degradálódott, elveszti jelentôségét, hiszen legitimációs forrásaként nem önmagát, hanem a gazdasági hasznot nevezzük meg. Pedig a profités az etika a racionalitás és a respektus nem redukálhatók egymásra, döntéseinknél figyelembe kell vennünk mindkét dimenzióban az elért eredményeket, övetkezményeket.

Ráadásul az üzleti érdek nemcsak kétes, de ingatag alap is a felelôs tevékenységre. Ha azért vagyunk etikusak, mert az kifizetốdó, abból következik, hogy amennyiben nem kifizetódó, az etika elfelejthetó. Pedig épp akkor lenne legnagyobb szükségünk az etikára, ha gazdasági és társadalmi problémáktól szenvedünk. A mostani gazdasági válság épp ezért megmutathatja, mely cégek gondolták, gondolják komolyan az etikai felelósségvállalást.
Az üzleti érdek, az etika és a profit együttmozgása csak feltételesen, lokálisan és idôlegesen igaz. A CS csak egy meghatározója az üzleti sikernek, a többi tényezó segítheti, de tehet is ellene. „A CSR csak annyir fenntartható, mint a cég, amelyik csinálja." (Financia Times, idézi: Vogel, 2006: 43. o.) Így tulajdonképpe cég és kontextus-függó, mennyire kifizetődố a felelốsség. Erkölcsös és nem erkölcsös tevékenységet is lehet hatékonyan, de nem hatékonyan is végezni, a pénzügy és nem pénzügyi eredmény között nincs egyértelmu fügovényszerú kapcsolat. Felelōtlenség azt sugall hogy a felelősségteljes cselekvés mindig költség né hil jo Tón kül jár. Tovabbá etikátlan a morális dilemmát gazdasági önérdekre alapozni... A piacnak sok érdemleges jellemzője van, de a megfelelő ár kitúzésének erénye nem tartozik közéjük" (

Vogel (2006) hangsúlyozza, hogy az etika és a profit kapcsolata összetett, nagyon függ a társadalmi és intézményi kontextustól. Ahhoz, hogy az etika valóba kifizetôdố legyen, szükséges erôs jogi szabályozás, megfelelố ellenőrzéssel és kikényszerítéssel, érdeküket érvényesító érintettek, szociális kohézió, a szabadságjogok általános tisztelete, sajtószabadság, objektív média az információ gyors és szabad áramlása. Szintén fontos tényezô, hogy létezik-e versenytárs, helyettesito fontos tén nozón hetesít az ado vállalat termékét fogyasztani, ha tudjuk róla, hogy felelốtlenül viselkedik.

$\mathrm{Ha}$, és csak ha ilyen a társadalmi és szervezeti struktúra és kultúra, akkor az etika valóban kifizetődô. Az naivitás tehát, ha azt hisszük, az etika minden esetben $\mathrm{k}$ fizetốdő, de az is, ha nem hisszük, hogy alakíthatók úgy körülmények, hogy egyre kifizetődóbb legyen. Ezekne a körülményeknek a létrehozása és fenntartása nehéz és soha véget nem éró feladat, a legjobb, amit elérhetünk, egy tökéletlen és átmeneti egyensúlyi állapot, amit befolyásolhatnak külsố tényezők, de belülról is bomlásnak indulhat. Egyszerúen azért, mert a megnövekedett bizalom, amely a rendszer optimalizációjához elengeda csalásra, az egyensúly felborítására (Paine, 2000).

Azért veszélyes univerzális igazságként hangsúlyozni, hogy az etika kifizetődô, mert ezzel elaltatjuk saját gyanakvásunkat, és elfelejtjük kialakítani és k kényszeríteni a szükséges feltételeket, ezzel még az eddiginél is szélesebb utat engedve a mások kárára valo önérdekkövetésnek.

Az etika másodfajú kudarca tehát az, hogy nem elég, hogy nem tartjak fontosnak, de a piaci szerepló megtévesztésére kifejezetten hangoztatják fontossága pusztán opportunista indokból. Ezzel az eddiginél is szélesebb utat engedünk az önérdekkövetésnek, ráadául még messzebb kerülünk a valódi kérdések megváaszolasatoól, de feltevésétól is. Mivel a vállalatok többsége instrumentálisan hasznalja a CSR-eszközöket, a vallalati felelősség elveszti eredeti jelentését és jelentőségét, valamint esélyét arra, hogy valóban hozzájáruljon a globális problémák megoldásához, a fenntarthaóság eléréséhez.

\section{Piaci és kormányzati megoldások az etika}

Mint a Ford Pinto-esetnél láttuk az etika elsőfajú kudarcát - mikor figyelembe sem veszik - hosszú távon megoldhatja a kormányzat (szigorodó szabályozás, vagy súlyosabb szankciók alkalmazásával). A mostan ermék-visszahívásokat is részben a szigorúbb biztonági elôírások indokolják

De ezekben a kérdésekben sokat változott a piac, elsósorban a fogyasztók szerepe is. Bizonyítják ezt a tudatos fogyasztó mozgalmak, a fogyasztó bojkottok. A termékvisszahívások pedig - bár átmeneti kellemetenséget okoznak - inkább pozitív hatásúak a fogyasztói lojalitásra: az emberek úgy érzik, a vállalat felelósen gondolkodik, törődik a biztonságukkal, ,gondoskodik róluk", hiszen korrigálja a hibákat.

Szintén a piac szerepét mutatják az etikus befektetési lehetôségek, az etikus bankok is. A befektetók zempontjából fontos kérdés a kockázatkezelés. Amit már a mainstream banküzemtan és befektetési elmélet is elfogad, például, hogy a környezeti vagy reputációs ockázat nagyban meghatározza egy beruházás, sốt az gész cég pénzügyi sikerét is.

Bár nincs egyértelmú bizonyíték arra, hogy az etikai elvek alapján megválogatott portfóliók jobban teljesítenének, mint a hagyományosak (hiszen az etika nem mindig kifizetődó), az etikus befektetési alapok népszerúsége gyors növekedés után változatlanul magas ${ }^{7}$ Vannak, amelyek a felelốtlen cégeket zárják ki bizonyos negatív kritériumok alapján (pl. a dohány, alkohol, olaj zit́v kritériugánással foglalkozó cégeket), mások pozeliv krifécha az átlagosnál felelösebbekm ve papírjaik közé. Az elsővel kapcsolatban

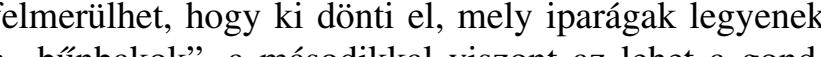
a „bűnbakok”, a másodikkal viszont az lehet a gond, hogy túl inkluzívvá válik, és ,,vakok közt a félszemúeet" jutalmazza. Ráadásul mindkét esetben kérdéses a döntést megalapozó információk forrása, és hogy miért követelnek meg az alapok az etika mellett bizonyos minimális, rövid távú pénzügyi megtérülést is - ezzel kizárva az elsődlegesen környezeti vagy társadalmi célú, pénzben csak hosszabb távon megtérüló projekteket.
VEZETÉSTUDOMÁNY

\section{VEZETÉSTUDOMÁNY}


Akárhogyan is, valójában minden esetben, amiko az érintettek kényszerítik ki a vállalattól a felelőssé vállalását, valójában a piac korrigálja szereplőin át az etika elsőfajú kudarcát: a vállalatvezetés etikai hozzáállásának, elkötelezettségének hiányát ${ }^{8}$. Ugyanígy, ahogy láttuk, a kormányzati szabályozás is pótolhatja a hiányzó etikát. A képlet tehát a 2. ábrán látható módon változik.

A piac, a kormányzat, az etika és a közjó összefüggésrendszere

etiac

Továbbra is kérdés azonban, elég tudatosak és józanok vagyunk-e az etika másodfajú kudarcának korrigálására, egyáltalán felismerjük-e azt.

Mikor egy nagy áruházlánc CSR-díjat kap, és a következő héten elfogadhatatlan munkakörülményeiról cikkeznek, az jó példa erre a felismerésre, korrigálásra. Amikor helyén tudjuk kezelni a vállalatok „zöldremosását”, mikor teljeskörúen megpróbáljuk feltérképezni egy vállalat tevékenységét, és nem csak a pozitív tartalmú PR-ra, kommunikációra figyelünk, amikor a valódi és a látszatetika különbségéról folytatunk tudományos vitát, máris bekapcsoltuk a piaci mechanizmust. De sajnos erre kevés, elszórt példa van csak, nem beszélhetünk szisztematikus, megnyugtat megoldásról. Jellemzóbb, hogy elhisszük, pozitívan értékeljük a látszólag felelós tevékenységet.

Joel Bakan, a Corporation címú kultuszmú szerzóje egyenesen „sármos pszichopaták”-nak hívja a CSR-rel operáló vállalatokat. Ő a mai helyzet kialakulásáért a részvénytársaságokat, azok korlátolt felelósségét, jog személyiségét teszi első helyen felelőś. A vállalatok

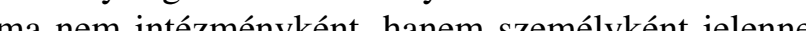
meg, kilïnös a fogyastok elott. A reklámokban a vállalat a baŕlunk, a szomsédunk, bizonyos eseck-

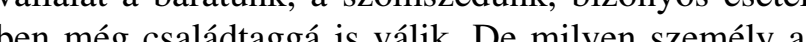
kinek lesón, sog is válk. De milyen személy az, akinek legfóbb, sốt egyetlen küldetése saját önérdekének elérése? Valós személyeknél ez a pszichopát definíciója (Bakan, idézi: Doane, 2005: 26. o.)!

A szervezetekben dolgozó emberek természetesen nem pszichopaták, de a szervezet elvárásai mia állandó kognitív disszonanciában élnek. Míg otthon szeretố családapák, a közösség felelốs tagjai, addig a vállalatnál csak egy célt követhetnek: a vállalat értékének állandó, határtalan növelését'. Ezt a disszonanciát csökkenti némiképp a CSR, hiszen csökkenti a vállalatvezetốk és alkalmazottak lelkiismeret-furdalását De ez csak egy álarc: a fó cél továbbra is a profittermelés. Minél elfogadottabb és üdvözöltebb a CSR, annál sármosabbnak látjuk a továbbra is pszichopata vállalatokat. Ez még veszélyesebbé teszi óket, mert az érintettek hajlamosak a látszat után ítélni, és elaltatják egészséges gyanakvásukat.

Ez az USA, de mi történik Európában? Maga az Európai Unió is a CSR technokrata, instrumentális Európai Uni használatát szorgalozera sziltáciok, az bileti érek lét és elhallgatra az etikus cselekvés költségeit, a profit nem etikusan megszerezhetó részének elveszlésêt hogy a fenntarthatóság mint makrocél mikroeszköze deklaráltan az EU versenyképességének fokozása érdekében bevetendő stratégiai fegyver.

A közgazdaságtan elméleti rendszere, valamint a vállalatok törvényi szabályozása, de még a CSR-re vonatkozó szupranacionális ajánlások is, továbbra is a vállalati önérdekkövetésre és pénzügyi haszonmaximalizálásra épülnek, így maga a rendszer az ami csalásra etikátlanságra és a CSR opportunista használatára ösza menedzsereket.

Bár világosan látszik, hogy a piac láthatatlan keze önmagában nem alkalmas a közjó elérésére, nem lépünk túl alapvetố elméleti törvényszerúségein, hiedelmein akkor sem, mikor pedig pont erról lenne szó, hiszen az etika szerepét próbáljuk operacionalizálni. Az etika másodfajú kudarcának valós megoldása az lenne, ha elfogadnánk, és rendszerszinten használnánk többdimenziós értékelési kritériumokat, és nem próbálnánk meg minden értéket pénzre redukálni. A közgazdaságtan alapvetố rendszerét és eszköztárát kell újradefiniálnunk, vagy ha tetszik, visszatérnünk az alapokhoz, Polányi (1976) szubsztantív gazdaságértelmezéséhez, ahol a pénz és a profit csak eszköze a társadalmi szïkségletek kielégítésének - mely a gazdasá al szin-

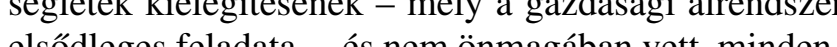
elsődleges feladata -, és nem önmagában vett, minden-

\section{Konklúzió}

A cikkben a piac és a kormányzat kudarcaiból kiindulközjó elérését célzó harmadik rendszer, az etikai felelôsség kudarcait. Statisztikai analógiát használva első́fajú kudarcként azonosítottam, mikor az etikát nem veszik figyelembe, pedig szükség van rá (ahogyan a nullhipotézist is elvetjük, holott igaz)
Másodfajú kudarcként kezeltem ugyanakkor az etika profitnövelést célzó használatát, mely megtéveszti az érintetteket, így még szélesebb utat enged az opport nista üzleti tevékenységnek (ahogyan másodfajú hib nak nevezzük azt, ha a nullhipotézist elfogadjuk, pedi hamis).

Meglátásom szerint a három rendszer egymást nemcsak kiegészíti, de kölcsönösen korrigálja is. Ez az elsôfajú kudarc esetében általánosabb, a másodfajú kudarc megoldásához azonban a gazdasági élet alapvetéseinek átfogalmaźśŕ, az önérdek és az egydimeniós telje sítményértékelés helyett egy új, holiszikubb szo letû́ közgazdaságra van szükség.

\section{Lábjegyzet}

A cikk és a mögötte álló kutatás a Budapesti Corvinus Egyetem TAM-4. 2.1.B-09/1/KMR-2010-0005 projektijén belül valósult meg.

A társadalmi felelő̂sségvállalás fogalmának kialakulását legtöbbszzör Howard Bowen 1953-ban megjelent, „So
of the Businessmen” címú könyvéhez kötï̈k. Ezert is talatható meg mind az angol, mind a magyar szóban szotokent a ,response" és a „,felel”, vagyis a „választ ad” kifejezés. A vállalatok egyébként nagyon ügyesen kezelik a ,személy-e a
vállalat?" kérdést. Amennyiben szerzódést akarnak kötni, alkalmaznak valakit, eladnak vagy vesznek, hangsúlyozzák jogi sze. egységes személyként" érvet.

A latin kifejezés eredetileg: ,nemo dat quod non habet - senki nem adhatja oda azt, amije nincs" (Goodpaster, 2007: 279. o.). "Zsolnai László (2000) például ezen mutatja be Felelốs döntéshozatali modelljét.

Ha tényleg kimagaslóan teljesítenének ezek az alapok, az azt ereményezné, hogy befektetésis jegyeiket sokan vennék, ami a kereslet-kínálat torvenyei szerint megszuntetné a magasabb hozamot. a nyilvánosságot a médít mely a kïlönböző szer plák érele véleményét segít artikuláln

Ez a Goodpaster- (2007, 26. o.) féle morális skizofrénia.

${ }^{10}$ Berenbeim (2006) alapján ezt nevezzük ,etikai önuralomnak",

\section{Felhasznált irodalom}

Angyal Á. (1997): Az értékrendváltásról, az üzleti siker és erkölcs összefüggs

gval Á. (2003): Nézetek az erkölcsról, avagy a malaszt termeszete. Budapest: Aula Kiadó

Bába P. (2009): Amerikában történt. http://v8cars.hu/mag. php?cikk=cikk0113

Bakan, J. (2005): The Corporation. Beteges hajsza a pénz és a hatalom után. Budapest: Független Média Kiadó

Berenbeim, $R$. (2006): Finding Space to Discuss Ethics. in: ZSOLNAI, L. (ed.): Interdisciplinary Yearbook of Busness Ethics, 1. évf. 1. szám, 197-199. ouckaert, L. (2006a): The Ethics Management Paradox. in: Zsolnai, L. (ed.): Interdisciplinary Yearbook of Business Ethics, 1. évf. 1. szám, 191-194. o.

Bouckaert L (2006b): When More Ethics Create Less Ethics: Some Further Clarifications of the Ethics Managemen Paradox. in: Zsolnai, L. (ed.): Interdisciplinary Yearbook of Business Ethics, 1. évf. 1. szám, 207-210. o.

Ben, H.R. (1953): Social Responsibility of the Businessmen. New York: New York University Press as (D. (205): The My ho CSR - The problen with assuming that companies can do well while also doing

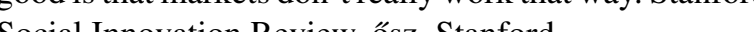

Dowie, M (1977): Pinto Madness. http://motherjones.com/ politics/1977/09/pinto-madness

(192): A „„zemnely a közösségben” paradigma. . Kindler, J. - Zsolnai, L.: Etika a gazdaságban. Budapest. Keraban Kony

is is to increase its profits. New York Times Magazine,

Goodpaster, K.E. - Matthews, G.B. (1982): Lehet-e a vállalatnak lekikismerete? in: Boda, Zs. - Radácsi, L.: Vállaati etika. Budapest. Budapesti Kozgazdaságtudomány

Goodpaster, K.E. (2007): Conscience and Corporate Culture. Oxford: Blackwell Publishing

Toole, J. (1991): Tegyél jót és hajts hasznot! - A „Busines Enterprise Trust Award". in: Pataki Gy. - Radácsi, L. (2000): Alternatív kapitalisták. Szentendre: Ưj Paradig ma Kiadó, 45-69. o.

L.S. (2000): Does Ethics Pay? Business Ethics Quarterly, 10. évf. 1. szám, 319-330. o.

Ponyi K. (1976): Az archaikus társadalom és a gazdaság

szemlelet. Budapest: Gondolat
Porter, M.E. - Kramer, M.R. (2002): The Competitive Advantage of Corporate Philantropy. Harvard Business Review, december, $1-16$.

Porter, M.E. - Kramer, M.R. (2011): Creating Shared Value. Harvard Business Review, január-február, 62-77. o.

Sen, A. (1993): Van-e az üzleti elet etikájának gazdasági jelentôsége? Közgazdasági Szemle, 15. evf. 2. sz., 101-109. o démiai Kiadó

Vogel, $D$. (2006): The Market for Virtue - The Potential and Limits of Corporate Social Responsibility. Washington, D.C.: Brookings Institution Pres

West, E.G. (1994): Economic Progress, Morality and Civic Virtue: The Legacy of Adam Smith. WEA Meetings-re készittett elóadás, július 3 . solnai L. (2000): A döntéshozatal etikája. Budapest: Kos-
suth Kiadó

Cikk beérkezett: 2011. 10. hó

Lektori vélemény alapján véglegesítve: 2011. 11. hó 